\title{
Transformasi Jaminan Kebendaan Menjadi Jaminan Tunai dalam Penjaminan Kredit Sindikasi Internasional*
}

\author{
T. Murwadji \\ Fakultas Hukum Universitas Padjadjaran Bandung \\ Jl. Dipati Ukur No. 35 Bandung \\ mtarsisius@yahoo.com
}

\begin{abstract}
This research studies: first, legal problem of Banking Guaranty Law in International Syndication Loan Collateral; second, mechanism of fixed collateral to cash collateral transmission which can be implemented in International Syndication Loan Collateral in Indonesia. Third, perspective of fixed collateral to cash collateral transformation in International Syndication Loan Collateral for the development of Civil Law in Indonesia. The method used was normative juridical using qualitative descriptive analysis method. The research findings conclude: First, the prevailing collateral law in Indonesia currently has not yet given assurance to the infrastructure project management to be trusted in channeling great amount of fund from International Loan Syndication. Second, Collateral Legal System in Indonesia is still unable to settle some problems, such as large amount of collateral value, small amount of collateral types which is not equal with the amount of loan limit, the relatively large value change of project, and loan execution involving other country's legal system. Third, regulation perspective on the transformation and transmission of fixed collateral into cash collateral can be conducted in two alternatives.
\end{abstract}

Key words : Bank guaranty, SWIFT, collateral law

\begin{abstract}
Abstrak
Penelitian ini mengkaji: pertama, permasalahan hukum dari Hukum Jaminan Perbankan di Indonesia dalam penjaminan Kredit Sindikasi Internasional. Kedua, mekanisme transmisi jaminan kebendaan (fixed collateral) menjadi jaminan tunai (cash collateral) yang dapat diterapkan dalam penjaminan Kredit Sindikasi Internasional di Indonesia. Ketiga, perspektif transformasi jaminan kebendaan (fixed collateral) menjadi jaminan tunai (cash collateral) dalam penjaminan Kredit Sindikasi Internasional bagi pengembangan Hukum Perdata di Indonesia. Metode penelitian yang digunakan adalah yuridis normatif, dengan metode analisis diskriptif kualitatif. Hasil penelitian menyimpulkan: pertama, sistem hukum jaminan yang berlaku pada saat ini di Indonesia belum menjamin kepastian bagi para pengelola proyek infrastruktur dalam memperoleh kepercayaan penyaluran dana yang besar dari sindikasi kredit internasional. Kedua, Sistem Hukum Jaminan di Indonesia saat ini belum dapat mengatasi permasalahan: nilai jaminan yang besar, jenis jaminan yang nilainya kecil yang tidak sepadan dengan besarnya plafon kredit, terjadinya perubahan nilai proyek yang relatif besar dan eksekusi jaminan yang melibatkan sistem hukum negara lain. Ketiga, perspektif pengaturan tentang transformasi dan transmisi jaminan kebendaan menjadi jaminan tunai dapat dilakukan dengan dua alternatif.
\end{abstract}

Kata Kunci : Bank garansi, SWIFT, hukum jaminan

* Berdasarkan Hasil Penelitian Andalan Fakultas Hukum UNPAD tahun 2012 


\section{Pendahuluan}

Bank merupakan salah satu lembaga keuangan yang paling penting dan memiliki peranan besar dalam kehidupan perekonomian masyarakat. Tatanan perekonomian global sepertinya telah memperkuat posisi perbankan sebagai pilar utama dalam menunjang pertumbuhan ekonomi secara internasional maupun domestik masing-masing negara. Implementasi dan eksistensi perbankan tersebut, bank bertindak sebagai salah satu bentuk lembaga keuangan yang bertujuan sebagai "financial intermediary" dengan usaha utama menghimpun dan menyalurkan dana masyarakat serta memberikan jasa-jasa lainnya dalam lalu lintas pembayaran. Kedua fungsi tersebut tidak bisa dipisahkan, sebagai badan usaha, bank akan selalu mendapatkan keuntungan yang sebesar-besarnya dari usaha yang dijalankan. Sebaliknya sebagai lembaga keuangan, bank mempunyai kewajiban pokok untuk menjaga kestabilan nilai uang, mendorong kegiatan ekonomi, dan memperluas kesempatan kerja. ${ }^{1}$

Kredit merupakan kegiatan usaha utama yang harus dilakukan oleh bank karena pendapatan terbesar dari usaha bank berasal dari pendapatan kredit yaitu berupa bunga dan provisi pinjaman. Menurut M. Bahsan, apabila ditinjau dari sudut perkembangan perekonomian nasional dan internasional akan dapat diketahui betapa besar peranan yang terkait dengan kegiatan perkreditan pada saat ini. Berbagai lembaga keuangan, terutama bank konvensional, telah membantu pemenuhan kebutuhan dana bagi kegiatan perekonomian dengan memberikan pinjaman uang antara lain dalam bentuk kredit perbankan. ${ }^{2}$

Di Indonesia fungsi perbankan ini dituntut untuk menjadi media pembangunan guna mendukung pelaksanaan program pembangunan nasional. Tugas bank guna mendukung pembangunan nasional ini, secara jelas disebutkan dalam UndangUndang Nomor 10 Tahun 1998 tentang Perbankan, yang menjelaskan bahwa Perbankan Indonesia bertujuan menunjang pelaksanaan pembangunan nasional dalam rangka peningkatan, pemerataan, dan stabilitas nasional ke arah penigkatan kesejahteraan rakyat banyak, sehingga jelas sekali bahwa fungsi perbankan di Indonesia di samping sebagai penghimpun dan penyalur dana masyarakat memiliki peran untuk melaksanakan pembangunan nasional. ${ }^{3}$

\footnotetext{
${ }^{1}$ Rahman Usman, Aspek-Aspek Hukum Perbankan di Indonesia, PT. Gramedia Pustaka Utama, Jakarta, 2001, hlm. 59. ${ }^{2}$ M. Bahsan, Hukum Jaminan dan Jaminan Kredit Perbankan Indonesia, PT Raja Grafindo Persada, Jakarta, 2007, hlm. 2. ${ }^{3}$ Ignatius Ridwan Widyadharma, Hukum Sekitar Perjanjïan Kredit, Universitas Diponegoro, Semarang, 1997, hlm. 1.
} 
Salah satu bentuk perkembangan kredit yang ada dewasa ini adalah pemberian kredit sindikasi. Kredit sindikasi mulai tumbuh di pasar modal dalam negeri di Amerika Serikat pada 1950-an, sedangkan evolusi di pasar modal internasional di London terjadi baru kemudian pada 1960-an. Kredit sindikasi di pasar internasional di London perkembangannya ditunjang oleh kenyataan bahwa kredit dapat diberikan dalam semua mata uang yang convertible, yang berbeda dengan pasar Amerika Serikat di Wall Street, dimana kredit sindikasi diberikan hanya dalam mata uang dolar Amerika Serikat sekalipun penerima pinjaman adalah pihak asing. Dalam hal kredit sindikasi diberikan dalam berbagai mata uang, yaitu yang biasa disebut multicurrency loans, dana disediakan tidak hanya dalam satu mata uang sesuai dengan pilihan penerima pinjaman. ${ }^{4}$

Bentuk kredit sindikasi di Indonesia kemudian berkembang pula sejalan dengan meningkatnya volume dan jenis kegiatan perekonomian nasional, dimana kebutuhan pembiayaan yang diperlukan juga semakin beragam dan terus meningkat. Dalam keadaan demikian, pembiayaan secara bersama oleh beberapa bank dalam bentuk kredit sindikasi merupakan salah satu langkah yang rasional dan positif mengingat semakin besarnya kebutuhan dana serta panjangnya jangka waktu kontruksi berbagai jenis proyek, seperti pembangunan Jalan Tol, Proyek Pembangkit Listrik, dan mega proyek lainnya.

Mengingat besarnya dana segar yang diperlukan, biasanya kredit diberikan oleh beberapa bank, atau yang sering disebut dengan kredit sindikasi. Adakalanya suatu bank tidak mampu atau tidak cukup dana untuk meminjamkan seluruh jumlah kredit yang dibutuhkan oleh debitur atau karena alasan pembatasan peraturan perundang-undangan khususnya mengenai jumlah pemberian kredit yang diijinkan atau batas maksimum pemberian kredit (legal lending limit atau BMPK) yang ditetapkan oleh otoritas yang berwenang melalui Pasal 11 Undang-Undang Nomor 7 Tahun 1992, sebagaimana telah diubah oleh Undang-Undang Nomor 10 Tahun 1998, tentang Perbankan.

Selain hal tersebut walaupun suatu bank mampu memberikan kredit dalam jumlah yang besar kepada debitur, namun bank sebagai kreditur belum tentu bersedia sebagai satu-satunya kreditur dalam pemberian kredit. Dalam pemberian kredit tentunya memiliki risiko, semakin besar jumlah kredit, semakin besar pula

${ }^{4}$ Sutan Remy Sjahdeni, Kredit Sindikasi Proses Pembentukan dan Aspek. Hukum, PT. Pustaka Utama Grafiti, Jakarta, 1997, hlm.1. 
jumlah risiko yang harus ditanggung oleh kreditur. Berkaitan dengan risiko tersebut, tentunya kreditur pemberi kredit, tidak mau memikul risiko yang besar, walaupun jaminan telah diberikan oleh debitur. Oleh karena itu untuk memperkecil risiko tersebut suatu bank dapat mengajak bank yang lain sebagai kreditur untuk bersamasama memberikan kredit dalam jumlah yang besar kepada debitur yang memerlukannya. ${ }^{5}$

Dalam dunia bisnis perbankan, kredit sindikasi atau "syndicated loan" secara umum sering diartikan sebagai kredit yang diberikan oleh beberapa kreditur sindikasi yang biasanya terdiri dari bank-bank/atau lembaga-lembaga keuangan lainnya pada seorang debitur yang biasanya berbentuk badan hukum : untuk membiayai 1 (satu) atau beberapa proyek. Kredit tersebut diberikan secara sindikasi mengingat jumlah yang dibutuhkan untuk membiayai proyek tersebut sangat besar sehingga tidak mungkin dibiayai oleh kreditur tunggal. ${ }^{6}$

Dalam pelaksanaan proses kredit sindikasi tersebut akan terdapat beberapa kreditur sebagai peserta sindikasi. Dengan demikian apabila ditinjau dari aspek hukum, dapat dikatakan bahwa kredit sindikasi merupakan hubungan-hubungan hukum yang sangat kompleks dari beberapa subyek hukum yang mengikatkan diri terhadap suatu perjanjian. Hubungan hukum antar peserta kredit sindikasi satu sama lain dan debitur harus diatur secara jelas, hak dan kewajiban dalam perjanjian kredit sindikasi.

Satu hal yang perlu diperhatikan adalah dalam praktik industri perbankan di Indonesia penjualan atau pengalihan piutang kredit (Loan Sales atau Sales of Loan Facility), dalam kredit sindikasi baik antar anggota sindikasi kredit maupun pihak ketiga dengan membuat perjanjian jual beli piutang kredit dan perjanjian Cessie dilakukan tanpa persetujuan dari pihak debitur namun hanya disetujui oleh Agen Bank.

Para kreditur dari kredit sindikasi dalam praktek tidak hanya berasal dari satu negara tetapi dimungkinkan berasal dari negara lain. Dalam hal ada satu atau lebih kreditur yang berasal dari negara lain maka terjadilah kredit sindikasi internasional.

Dalam kredit sindikasi, permasalahan utama adalah menyangkut jaminan yang dapat dipergunakan untuk penjaminan kredit tersebut. Permasalahan tersebut adalah: plafon dana pinjaman sangat besar karena nominalnya di atas Batas

${ }^{5}$ Fennike Kristianto, Kewvenangan Menggugat Pailit dalam Perjanjian Kredit Sindikasi, Minerva Athena Pressindo, Jakarta, 2009, hlm. 4.

${ }^{6}$ Ibid., hlm. 13. 
Maksimal Pemberian Kredit dari bank-bank peserta; jumlah jaminannya banyak karena jaminan kebendaan yang ada nilainya terbatas; jenis jaminan kebendaannya juga banyak, misalnya: tanah, mobil, emas, bangunan, saham dan benda-benda lain yang mempunyai nilai ekonomis; dan letak jaminan tersebut biasanya tersebar, bahkan berada di luar negeri sehingga proses eksekusinya menjadi sulit. Dengan demikian jaminan kebendaan sangat tidak efektif dan efisien untuk dijadikan jaminan dalam kredit sindikasi internasional.

Cara yang dapat ditempuh adalah dengan jaminan tunai (cash collateral) berupa deposito atau surat-surat berharga yang dapat dicairkan secara tunai atau dengan kata lain dapat diuangkan. Penjaminan kredit perbankan dengan jaminan tunai juga mengalami kesulitan karena ketiadaan uang tunai, kalau pengusaha mempunyai uang tunai maka tidak perlu mencari pinjaman melalui kredit sindikasi internasional.

Jalan keluarnya adalah dilakukan transformasi (pengubahan) dari semula jaminan kebendaan menjadi jaminan tunai. Mekanisme transformasinya adalah jaminan tersebut secara fisik disimpan di suatu bank besar yang berstatus sebagai bank penerbit, kemudian dinilai nominal jaminannya sebagai dasar diterbitkannya dokumen-dokumen pendukungnya, untuk selanjutnya dimasukkan kedalam rekening bank penerbit tersebut.

Setelah dimasukkan ke dalam rekening bank maka statusnya sudah seperti rekening uang tunai, misalnya dapat ditransfer ke rekening lainnya, dapat untuk menjamin kredit perbankan dimana saja (internasional), bahkan dapat dijadikan surat berharga. Perbedaannya adalah kalau uang tunai yang tercantum rekening suatu bank maka dana tersebut dapat diambil atau dicairkan atau diuangkan, sedangkan yang berasal dari jaminan kebendaan tidak dapat diuangkan atau dicairkan.

Dalam penelitian ini peneliti akan meneliti apakah Sistem Hukum Perbankan yang berlaku di Indonesia sekarang ini sudah menjamin kepastian hukum dan sesuai dengan prinsip efektivitas dan efisiensi dalam penjaminan kredit sindikasi internasional. Permasalahan ini perlu diteliti untuk mengetahui perlu atau tidak dilakukan transformasi jaminan kebendaan menjadi jaminan tunai dalam kredit sindikasi internasional pada bank-bank Indonesia.

Permasalahan selanjutnya yang akan diteliti peneliti adalah mengenai mekanisme transformasinya. Mekanisme transformasi harus jelas, dijamin 
kepastiannya, sederhana, efektif dan efisien, serta yang paling penting adalah bahwa mekanisme itu diakui secara internasional dan dapat diintegrasikan ke dalam sistem transmisi perbankan internasional.

Permasalahan selanjutnya adalah mengenai perspektif atau manfaat pada masa depan dari transformasi jaminan ini bagi Hukum Jaminan Nasional. Penelitian ini juga diharapkan memberi solusi bagi Hukum Jaminan Nasional yang berlaku saat ini yang ternyata kurang kondusif untuk penjaminan kredit dalam jumlah yang besar. Pengembangan hukum jaminan pada saat ini sangat penting karena proyekproyek besar banyak yang sulit dicarikan kreditnya karena permasalahan jaminan.

\section{Rumusan Masalah}

Berdasarkan uraian permasalahan dalam pendahuluan, maka perumusan masalahnya adalah sebagai berikut: pertama, bagaimana permasalahan hukum dari Hukum Jaminan Perbankan di Indonesia dalam penjaminan Kredit Sindikasi Internasional? Kedua, bagaimana mekanisme transmisi jaminan kebendaan (fixed collateral) menjadi jaminan tunai (cash collateral) yang dapat diterapkan dalam penjaminan Kredit Sindikasi Internasional di Indonesia? Ketiga, bagaimana perspektif transformasi jaminan kebendaan (fixed collateral) menjadi jaminan tunai (cash collateral) dalam penjaminan Kredit Sindikasi Internasional bagi pengembangan Hukum Perdata di Indonesia?

\section{Tujuan Penelitian}

Tujuan penelitian ini adalah untuk mengetahui: Pertama, pokok permasalahan hukum dari Hukum Jaminan Perbankan di Indonesia dalam penjaminan Kredit Sindikasi Internasional. Kedua, mekanisme transmisi jaminan kebendaan (fixed collateral) menjadi jaminan tunai (cash collateral) yang dapat diterapkan dalam penjaminan Kredit Sindikasi Internasional dan diterima di kalangan perbankan di Indonesia dan dapat diintegrasikan dalam transmisi erbankan internasional. Ketiga, perspektif transformasi jaminan kebendaan (fixed collateral) menjadi jaminan tunai (cash collateral) dalam penjaminan Kredit Sindikasi Internasional bagi pengembangan Hukum Perdata di Indonesia. 


\section{Metode Penelitian}

Metode pendekatan yang digunakan dalam penelitian ini adalah yuridis normatif, yaitu mengkaji hukum yang dikonsepkan sebagai norma atau kaidah yang berlaku dalam masyarakat dan menjadi acuan perilaku setiap orang. ${ }^{7}$ Oleh karena itu penelitian hukum yang dilakukan yaitu mengolah data yang diperoleh dari penelitian lapangan sebagai data primer yang selanjutnya dikaji lebih lanjut dengan mengacu kepada peraturan-peraturan tertulis maupun hukum lainnya yang terkait dengan bidang perbankan, khususnya tentang perjanjian kredit sindikasi dan pengalihan piutang kredit.

Penarikan kesimpulan dari hasil penelitian yang berupa data primer dan data sekunder dilakukan dengan metode analisis yuridis kualitatif, yaitu mengkaji dan menguji data melalui aspek-aspek hukum, tidak menggunakan rumus matematis dan selanjutnya disajikan dalam bentuk deskriptif karena bertitik tolak dari kaidah hukum yang berlaku di masyarakat. Kualitatif karena menguraikan data secara bermutu dalam bentuk kalimat yang teratur, runtut, logis, tidak tumpang tindih, dan efektif, sehingga memudahkan interpretasi data dan pemahan hasil analisis. ${ }^{8}$

\section{Hasil Penelitian dan Pembahasan}

\section{Permasalahan Hukum Jaminan di Indonesia dalam Kredit Sindikasi Internasional}

Benda atau aset yang merupakan objek jaminan menurut Sistem Hukum Jaminan sangat sulit dijadikan objek jaminan kredit untuk pembiayaan proyek besar karena:

Pertama, nilai jaminan berupa tanah, bangunan, mobil dan jaminan kebendaan lain menurut Hukum Jaminan Indonesia, yaitu hak tanggungan, gadai, hipotik dan fidusia nilainya sangat kecil untuk proyek besar yang dibiayai oleh kredit sindikasi internasional. Sebagai contoh: untuk Proyek Tol yang paling kecil nilainya, yaitu Tol Seroja (Soreang - Pasir Koja) nilainya Rp. 2.500.000.000.000,00 berarti nilai jaminan yang harus ada minimal 140\% dari nilai proyek atau Rp. 3.500.000.000.000,00. Kalau jaminannya berupa tanah misalnya, pasti dibutuhkan tanah yang sangat luas yang

${ }^{7}$ Abdulkadir Muhamad, Hukum dan Penelitian Hukum, PT Citra Aditya Bhakti, Bandung, 2004, hlm. 52. 
terdiri dari ratusan bahkan ribuan sertifikat. Dibutuhkan waktu yang lama dan biaya yang besar untuk mengurus, membutuhkan tempat yang luas dan rumit untuk menyimpan jaminan. Ketika terjadi wanprestasi, eksekusi jaminan yaitu pelelangan tanah yang luas dengan lokasi terpisah-pisah dan jumlah sertifikatnya sangat banyak maka diperlukan waktu yang lama serta biaya yang besar.

Permasalahan lebih rumit lagi dalam kredit sindikasi internasional adalah kalau antara bank penerbit jaminan tunai dan bank pemberi kredit dengan lokasi jaminan tanah berbeda negara. Perbedaan negara tersebut menimbulkan masalah Hukum Perdata Internasional, yang menyangkut hukum negara mana yang mengatur perjanjian kredit sindikasi internasional dan forum peradilan mana yang berwenang menyelesaikan sengketa serta mengeksekusi jaminan tersebut.

Kedua, untuk proyek-proyek besar, dalam praktik para pengusaha Indonesia "terpaksa" mendirikan badan hukum yang berstandar internasional, misalnya badan hukum yang didirikan di Singapura, Hongkong, Kualalumpur dan sebagainya. Pendirian badan hukum di luar negeri, terutama yang menganut Sistem Hukum Anglo Saxon, karena Sistem Transmisi Perbankan Internasional yaitu SWIFT (Society Worldwide Interbank Finance Tellecomunication) mengalami kesulitan karena keengganan untuk bertransaksi dengan badan hukum atau pengusaha di Indonesia karena sistem hukum Indonesia dianggap tradisional (lokal), yang artinya tidak berstandar internasional. Fakta hukum ini tentunya merugikan Indonesia karena pajak badan usaha pun mengalir ke negara lain. Dapat dikatakan bahwa Sistem Hukum di Indonesia merupakan salah satu "country risk" dalam pengurusan kredit sindikasi internasional.

Ketiga, nilai proyek di Indonesia, misalnya proyek tol seringkali berubah karena perubahan harga tanah dan harga materiil bahan untuk membangun jalan, misalnya semen, besi dan sebagainya. Perubahan nilai proyek ini harus diikuti dengan perubahan plafon dana dalam perjanjian kredit perbankan dan tentunya berdampak pada perubahan nilai jaminan. Perubahan tersebut tentunya tidak mudah dilakukan dengan Sistem Hukum Jaminan yang berlaku di Indonesia, dan seandainya dapat dilakukan memerlukan waktu yang lama, tenaga yang besar dan tentunya biaya yang sangat tidak terduga. Perubahan nilai proyek ini menjadi salah satu penyebab terhentinya pelaksanaan 30 ruas jalan tol di Indonesia sejak 1997 sampai sekarang.

Keempat, Pengawasan jaminan: Jaminan kebendaan, misalnya tanah, bangunan, mobil dan sebagainya yang di bawah penguasaan debitur dalam kenyataannya 
mudah dialihkan dan mudah rusak. Misalnya tanah dan bangunan yang terkena bencana alam atau dijual tanpa prosedur hukum yang benar. Dalam rangka pengamanan jaminan tersebut diperlukan pengawasan dan perawatan obyek jaminan.

Kelima, perubahan peruntukan: pembiayaan besar biasanya berupa pembiayaan jangka panjang minimal 5 tahun dan maksimal 20 tahun. Dalam rentang waktu yang panjang tersebut, biasanya obyek jaminan yang berupa tanah seringkali mengalami perubahan peruntukan, sehingga menyulitkan untuk dieksekusi. Misalnya saja pada waktu pengajuan kredit sindikasi internasional, obyek jaminan berupa tanah yang luas, semula tanah kosong namun kemudian terjadi perubahan peruntukan menjadi kawasan industri misalnya, pasti menimbulkan masalah hukum yang berat.

Keenam, pendokumentasian surat-surat jaminan. Bukti jaminan berupa suratsurat perlu didokumentasikan secara aman dalam jangka waktu yang lama. Untuk kredit yang besar, tentunya diperlukan jaminan yang banyak karena jaminan-jaminan tersebut nilainya kecil, berarti surat-surat bukti jaminannya pun banyak. Dengan demikian masalah penyimpanan dokumen surat-surat jaminan dan pengamanannya pun menimbulkan permasalahan.

Dari uraian tersebut di atas, Hukum Jaminan di Indonesia terbukti belum sepenuhnya menjamin kepastian hukum dalam proyek infrastruktur dengan dana besar yang berasal dari kredit sindikasi internasional. Selain itu Sistem Hukum Jaminan dalam hukum positif di Indonesia belum mengantisipasi pengaturan jaminan untuk kredit perbankan yang nilai plafonnya sangat besar.

\section{Mekanisme Transmisi Jaminan Kebendaan Menjadi Jaminan Tunai Dalam Penjaminan Kredit Sindikasi Internasional}

Menghadapi perkembangan dalam sistem keuangan dan jaminan global yang didukung oleh sistem telekomunikasi perbankan internasional tersebut, Hukum Perbankan dan Hukum Jaminan dalam Sistem Hukum Nasional harus dikembangkan dengan cara harmonisasi hukum dengan Sistem Keuangan dan Jaminan Internasional yang sudah menerapkan transmisinya dengan Sistem SWIFT (Society Worldwide Interbank Financial Telecommunication) dalam transmisi jaminan keuangan internasional. SWIFT sebagai lembaga internasional yang menyelenggarakan jaringan telekomunikasi untuk keseragaman bank-bank di seluruh dunia yang menjadi anggota SWIFT. 
Keamanan dan keabsahan berita dalam lalu lintas antar anggota adalah hal yang membedakan SWIFT dengan sarana lain seperti public network atau telex. SWIFT memiliki kegunaan sebagai sistem verifikasi dalam dunia perbankan dalam rangka memberikan suatu legitimasi atas bank garansi yang digunakan sebagai jaminan utama bagi para pihak yang melakukan transaksi bisnis atau bagi pemenuhan persyaratan suatu proyek atau pendampingan modal usaha, juga merupakan instrumen yang dapat diperjualbelikan karena memiliki nilai ekonomi sebagai transferable trading object.

Keberadaan sistem komunikasi antar bank melalui SWIFT ini sangat membantu transmisi jaminan tunai, termasuk hasil transformasi jaminan kebendaan, yang menghubungkan calon debitur, pemilik jaminan tunai, bank penerbit, bank koordinat, bank pembayar dan bank pemberi kredit.

Pihak yang bertanggung jawab terhadap penyelesaian wan prestasi dalam kredit sindikasi internasional adalah pemilik jaminan tunai melalui bank penerbit. Dalam transmisi SWIFT, bank koordinat berfungsi sebagai bank yang mengkoordinasikan komunikasi semua pihak yang terlibat, termasuk melakukan klarifikasi validitas jaminan dan ketersediaan dana yang akan disalurkan oleh bank-bank peserta sindikasi kredit internasional.

Salah satu produk jaminan tunai, termasuk hasil transformasi jaminan kebendaan, adalah bank garansi. Bank Garansi merupakan salah satu bentuk jaminan tunai yang dikeluarkan oleh bank, dalam hal ini adalah bank penerbit. Bank tersebut akan membayar kerugian akibat wanprestasi oleh pihak yang mengajukan penerbitan bank garansi kepada bank penerbit. Pembayaran tersebut dilakukan melalui pemindahbukuan rekening giro dari bank penerbit kepada bank pemberi kredit melalui bank koordinat.

Secara khusus bank garansi diterbitkan bagi nasabah yang sangat memerlukan, agar penggunanya dapat ditujukan sebagai elemen pertumbuhan ekonomi di Indonesia. Hal ini diperlukan karena nasabah bank terutama kelompok pengusaha tidak selalu membutuhkan fasilitas dalam bentuk uang tunai sebagai modal untuk mengembangkan bisnis, akan tetapi transaksi-transaksi tertentu seringkali membutuhkan surat pernyataan yang menjelaskan kesediaan bank untuk menjamin pemenuhan kewajiban pihak nasabah apabila saat tertentu nasabah lalai melaksanakan kewajibannya.

Berdasarkan prosedur perbankan dalam praktik transaksi bank garansi dilakukan melalui organisasi penyedia layanan pesan finansial global, yaitu SWIFT, yang memiliki 
peran penting dalam mengimbangi perkembangan industri keuangan sehingga tantangan kesiapan sektor jasa keuangan untuk setiap anggota negara pengguna SWIFT. Bank garansi secara ketentuan praktis merupakan instrumen perbankan yang tidak dapat dipisahkan dalam mengatur alur pembayaran jaminan di antara institusi keuangan masing-masing negara. Sampai saat ini transmisi bank dilakukan melalui SWIFT yang berkolaborasi dengan komunitas pengguna dan telah melakukan standarisasi pertukaran pesan oleh organisasi yang melakukan bisnis keuangan.

Pada bisnis internasional yang menggunakan bank garansi sebagai alat bertransaksi menggunakan SWIFT, hal ini dapat dilihat sebagai kesempatan besar bagi sesama pelaku bisnis untuk saling berbagi informasi mengenai praktik-praktik terbaik dalam industri serta menyepakati jalan terbaik untuk bekerjasama khususnya dalam ruang non kompetitif demi memenuhi tuntutan sektor keuangan Indonesia.

Jaminan tunai yang merupakan hasil transformasi dari jaminan kebendaan tertentu. Dari hasil penelitian lapangan, penulis memperoleh data tentang praktek transformasi jaminan kebendaan menjadi jaminan tunai, yaitu emas murni (logam mulia) yang dijadikan obyek jaminan kebedaan yang akan ditransformasikan kedalam nilai nominal mata uang tertentu. Benda yang dijaminkan disimpan dalam save deposit box pada bank tersebut. Sebagai contoh ada emas seberat 1.350 .000 kilogram yang diimaterialisasikan sebesar \$ US 35 miliar dan disimpan di salah satu bank besar dan terkenal di Eropa. Dokumen-dokumen yang diterbitkan dalam rangka transformasi jaminan tersebut meliputi: Acknowledgment As to Bank, Authentication Letter, Bank Coordinate, Bank Guarantee, Bank Statement for Promissorry Notes, Promissory Note, Certificate of Heritance and Madate, Confirmation Letter, Confirmation of Bank Guarantee, Custodian Safe Keeping Certificate, Proof of Fund, Proof of Gold, Safe Keeping Receipt, Verification Letter dan Acknowledgement Letter.

Dengan transformasi tersebut, atas permohonan pemilik atau orang yang dikuasakan (Legal mandate) benda-benda jaminan misalnya emas murni disimpan pada bank penerbit, kemudian oleh penilai (appraisal) independen dinilai harganya dalam bentuk mata uang suatu negara misalnya dollar AS. Selanjutnya nilai tersebut dimasukkan kedalam rekening bank dan dapat dijadikan jaminan pinjaman atau kredit lembaga pembiayaan atau bank. Jaminan inilah yang dimaksud dengan jaminan tunai hasil transformasi (cash collateral)

Transformasi jaminan kebendaan sampai menjadi cash collateral ini merupakan analogi dengan penerbitan uang. Bedanya kalau uang itu diterbitkan oleh Bank 
Sentral dan dapat dicairkan, sedangkan fixed collateral diterbitkan oleh suatu bank penerbit dan tidak dapat dicairkan tetapi dapat dipindahbukukan. Untuk masa yang akan datang, cash collateral ini dapat difungsikan sebagai surat berharga dan dapat dipersamakan dengan uang giral.

Pemilik dapat mengajukan permohonan penerbitan Bank Garansi atas dasar cash collateral tersebut. Selanjutnya, dengan mekanisme SWIFT, Bank Garansi tersebut dapat menjamin kredit-kredit bank dari negara yang menjadi anggota SWIFT. Dalam hal terjadi wanpresi pinjaman atau kredit maka dilakukan pendebetan nilai uang dari cash collateral yang terdapat dalam rekening bank penerbit kepada bank pemberi kredit atau pinjaman.

Sistem pengiriman bank garansi dilakukan melalui kode Message Type (MT) dalam SWIFT transmission, dalam transaksi bank garansi proses penerbitannya adalah melalui SWIFT MT 799. MT 799 merupakan pre advise yaitu format yang menggunakan kode awalan angka "7" sebagai pemberitahuan pertama untuk bertransaksi dan juga menerangkan atas keberadaan dana yang menjadi jaminan bank garansi. Kemudian format MT 799 ini dapat digunakan oleh bank penerima dengan tujuan untuk diverifikasi agar segala sesuatu yang tertera di dalamnya sesuai dengan kepentingan beneficiary pertama.

Setelah bank penerima menerima MT 799 kemudian ditindaklanjuti dengan mengirim balasan MT 199 sebagai bentuk kesediaan dan instruksi kepada bank penerbit agar mengirim MT 760 yang merupakan transmisi kedua dari pengiriman bank garansi. MT 760 merupakan bukti keterangan jaminan yang mengikat atas bank garansi yang dapat dipergunakan dalam menindaklanjuti proses transaksi perbankan terutama dalam penjaminan dana, sehingga bank penerima dapat segera memberikan atau mengucurkan dana kepada beneficiary setelah final verification dengan mengirim MT 199 atau MT 999, maka segala kewajiban dapat dipenuhi dan diketahui bahwa bank memblokir dana atau aset dan memiliki nilai lebih dari jumlah nominal yang dicantumkan dalam bank garansi.

Berikut adalah ilustrasi pengiriman SWIFT antar bank dalam transaksi bank garansi: 


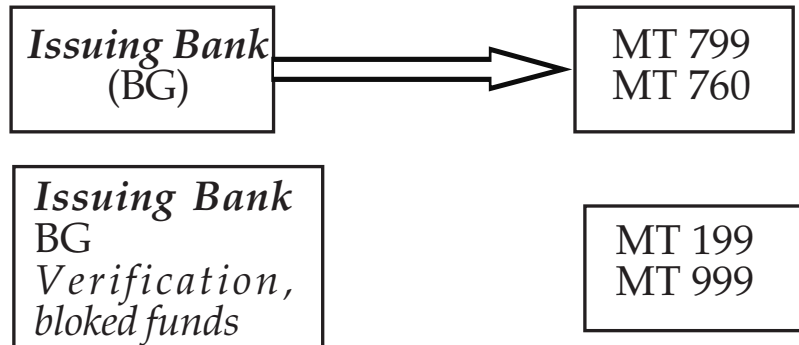

\section{Applicant}

Receiving Bank

(BG)

Receiving Bank

(BG)

Verification

Credit Line granted

Dipergunakannya sarana internet dalam proses komunikasi antar bank melalui SWIFT berpotensi besar muncul dan meningkatnya Cybercrime yang tidak hanya menjadi masalah nasional suatu negara tetapi juga menjadi masalah antar negara dan bahkan internasional. Hal ini berkaitan dengan karakteristik dari cybercrime yang bersifat internasional. Cybercrime dapat dilakukan di belahan dunia maupun dengan korban potensial yang sangat luas diberbagai belahan dunia. ${ }^{9}$

Dalam penelitian lapangan dapat diketahui bahwa sistem SWIFT sulit diterapkan di Indonesia baik oleh perusahaan menengah ataupun oleh perusahaan besar, dengan alasan:

Pertama, hambatan hukum: dalam praktik hukum di Indonesia, lembaga peradilan, notaris dan badan hukum, termasuk Perseroan Terbatas oleh bank dan lembaga pembiayaan asing dianggap bersifat lokal dan tradisional. Penyebabnya adalah hukum perjanjian yang berlaku di Indonesia masih terjemahan dari Buku III Burgerlijke Wetboek, praktek pengadilan dan birokrasi yang bersifat KKN (Korupsi, Kolusi dan Nepotisme). Akibat hukumnya adalah hukum Indonesia menjadi “Country Risk" yang dihindari oleh para pelaku bisnis internasional, perbankan dan lembaga pembiayaan internasional. Sebagai akibat hukum dari hambatan hukum adalah dipakaianya hukum asing dan forum asing sebagai lembaga peradilan yang dipakai dalam kontrak-kontrak perbankan.

Kedua, hambatan non hukum yang terutama adalah aspek ekonomi, yaitu besarnya biaya yang harus dikeluarkan. Penyebab utama hambatan ekonomi ini sebagian besar sebagai akibat hambatan hukum. ${ }^{10}$ Dengan dihindarinya hukum In-

\footnotetext{
9 Sigid Suseno, "Cybercrime, Pengaturan dan Penegakan Hukumnya di Indonesia dan Amerika Serikat”, Jurnal Ilmu Hukum Padjadjaran, Vol. XXXIII No. 1, April 2009, hlm. 41.

${ }_{10}$ Tarsisius Murwaji, "Dampak Otonomi Daerah Terhadap Investasi Pertambangan”, Jurnal Ilmu Hukum
} 
donesia, maka pengusaha Indonesia harus mendirikan perusahaan di Singapura, memakai pengacara dan notaris Singapura, mempergunakan Bank Singapura dan sebagainya yang tentunya memperbesar biaya yang harus dikeluarkan.

Hambatan non hukum lainnya adalah harus ada perorangan atau badan hukum yang memiliki aset yang dijaminkan, dapat berupa aset tetap (fixed collateral), atau aset berupa uang tunai (cash collateral), yang akan dijadikan jaminan dalam kredit sindikasi internasional. Jaminan aset tersebut sudah disimpan di bank-bank international, misalnya Union Bank Swisterland (UBS) di Jenewa Swiss, Hongkong Shyanghai Bank Corporation (HSBC) London atau Barclay Bank di London. Jaminan tersebut disewa oleh pengguna jaminan (debitur) dengan harga 6-8\% dari Aset jaminan yang disewa. Besarnya aset jaminan adalah 140\% dari plafon kredit. Biaya SWIFT terlalu besar, yaitu US \$ 194,000,00 atau kurang lebih harus disiapkan Rp. 2.000.000.000,00. Biaya ini tentunya tidak mudah diperoleh para pengusaha lokal, karena pengusaha lokal pinjam kredit perbankan di Indonesia sebesar Rp. 2.000.000.000,00 sudah sangat sulit.

Biaya pejabat bank khusus (Bank Officer), notaris publik, dan konsultan hukum perbankan di luar negeri sangat besar. Biaya untuk pendirian badan hukum yang berstandar internasional, misalnya didirikan di Singapura, yaitu British Virgin Island dengan biaya pendirian US \$30,000,00

\section{Perspektif Jaminan Tunai dalam penjaminan Kredit Sindikasi Internasional}

Penerapan Sistem SWIFT di Indonesia tidaklah mudah, perlu persiapanpersiapan berupa pembenahan infra struktur hukum atau penulis menyebutnya "legal infra structur" yang baru, yang meliputi Hukum Perjanjian, Hukum Jaminan, Hukum Perbankan, debirokratisasi peradilan, dan perijinan. Pembenahan ini memang harus direncanakan dengan sebaik-baiknya. Pembenahan ini memerlukan waktu yang sangat lama. Tanpa adanya pembenahan "legal infrastructur" tersebut maka fakta hukum seperti sekarang ini tetap berlanjut, Sistem Hukum akan terus menerus menjadi resiko negara (country risk). Ironisnya seorang pengusaha WNI yang punya uang atau proyek besar pun "terpaksa harus" menjadi orang Singapura atau orang Hongkong untuk mempermudah menerapkan sistem SWIFT.

Dengan pembenahan "legal infrastructur" tersebut berarti terjadi pengembangan pranata: hukum perdata, hukum perbankan dan penanaman modal. Selain itu juga akan dilakukan pengembangan kelembagaan, mulai dari notaris, 
peradilan dan lembaga terkait. Dengan pengembangan "legal infra structur" tersebut berarti pula terjadi perubahan paradigma baru dalam Sistem Hukum Jaminan di Indonesia. Paradigma yang sedang dianut sekarang adalah jaminan dalam arti sempit (collaterla) bahwa barang yang dijadikan obyek jaminan ditujukan sebagai penutup resiko yaitu obyek pelunasan kredit atau pinjaman pembiayaan proyek karena apabila terjadi wanprestasi maka barang jaminan tersebut dijual melalui lelang dan hasilnya untuk pelunasan tunggakan kredit bank. Dalam paradigma baru, benda yang dijaminkan tetap dimiliki oleh pemilik jaminan tunai, bila terjadi wanprestasi maka jaminan tunai itu dialihkan melalui pemindahbukuan untuk pelunasan kredit bank. Jadi cash collateral tersebut hakekatnya sama dengan uang giro (giral).

Dalam praktek perbankan internasional, transformasi tersebut sudah menjadi kebiasaan dalam dunia perbankan, dengan produk yang berupa Bank Garansi (BG), atau Standby Letter of Credit (SBLC). Dalam praktek perbankan di Indonesia, transformasi dari jaminan benda menjadi jaminan tunai belum diatur dan jarang dilakukan karena banyaknya hambatan. Berdasarkan UU No. 23 Tahun 1999 tentang Bank Indonesia yang telah diubah dengan Undang-undang No. 3 Tahun 2004 tentang Perubahan Atas UU No. 23 Tahun 1999 mempunyai kewenangan untuk mengatur perbankan di Indonesia. Dengan kewenangan tersebut Bank Indonesia dapat mengatur transformasi jaminan kebendaan menjadi jaminan tunai melalui 2 alternatif, yaitu: Alternatif pertama, merevisi: Hukum Perjanjian, Hukum Jaminan, dan Hukum Badan Hukum, yaitu Undang-Undang No. 19 Tahun 2003 tentang Badan Usaha Milik Negara, Undang-Undang No. 40 Tahun 2007 tentang Perseroan Terbatas dan Undang-Undang No. 20 Tahun 2008 tentang Usaha Mikro, Kecil, dan Menengah. Dengan revisi sistem hukum ini diharapkan transmisi cash collateral melalui SWIFT dapat diatur dan masuk ke Indonesia sehingga dapat menjamin kredit besar dari bank-bank nasional maupun internasional yang berdomisili di Indonesia. Untuk melakukan alternatif pertama ini tentunya memerlukan waktu yang lama dan biaya yang sangat besar

Alternatif kedua, yaitu Bank Indonesia mengatur sistem transformasi jaminan dan komunikasi antar bank yang "mirip" SWIFT untuk tingkat nasional. Hasil penelitian yang dilakukan penulis menunjukkan bahwa transformasi jaminan benda (fixed collateral) jaminan tunai (cash collateral) sebenarnya dapat menggunakan dasar perjanjian gadai. Dasar pemikirannya adalah dalam proses transformasi tersebut isyaratkan penyerahan barang-barang berupa emas dan atau berlian dari pemiliknya 
kepada bank penerbit yaitu bank yang nantinya menerbitkan jaminan tunai (cash collateral), misalnya dalam bentuk Bank Garansi (BG).

Penyerahan nyata (feitelijke levering) dalam gadai tidak dimaksudkan untuk melakukan peralihan hak milik, bahkan Pasal 1152 ayat (2) KUH Perdata menegaskan bahwa hak gadai tidak sah apabila barang gadai tetap dibiarkan dalam kekuasaan pemberi gadai, ataupun apabila barang tersebut kembali ke tangan pemberi gadai atas kemauan kreditor. ${ }^{11}$

Pengaturan ini harus benar-benar memperhatikan harmonisasi pengaturan secara internasional sehingga nantinya kalau sistem ini sudah terbangun dapat diintegrasikan atau dihubungkan secara on line. Dengan pengaturan ini paradigma Sistem Hukum Jaminan benar-benar berubah dari paradigma tradisional menjadi paradigma modern yang efiktif, efisien dan jaminan kepastian hukum yang kuat.

Dengan pengembangan infra struktur hukum tersebut konsep ekonomi tentang kelangkaan dana investasi dalam pembangunan infra struktur dapat diselesaikan tanpa menimbulkan masalah baru yang lebih besar. Konsep pembangunan hukum harus bertujuan memfasilitasi agar memudahkan terjadinya efisiensi, produksi dan distribusi dalam rangka peningkatan kesejahteraan masyarakat. ${ }^{12}$

Perpektif yang lain adalah banyaknya aset jaminan yang disimpan di bankbank internasional yang dimiliki orang-orang Indonesia berupa emas yang sudah ditransformasikan ke dalam bentuk bank garansi yang siap dijadikan jaminan tunai (cash collateral). Apabila sistem SWIFT ini sudah diterapkan di Indonesia maka semua proyek infrastruktur yang permohonan kreditnya sudah disetujui oleh bank nasional maupun internasional dapat dijamin dengan bank jaminan tunai. Dengan demikian permasalahan jaminan untuk proyek-proyek infrastruktur dapat di selesaikan. Prinsip kehati-hatian harus dipegang teguh dalam transformasi jaminan benda (fixed collateral) menjadi jaminan tunai (cash collateral) karena adanya hal yang sulit bagi negara yang sedang berkembang untuk menciptakan kondisi pasar yang mendekati sistem pasar yang ada di negara maju. ${ }^{13}$

Untuk membuktikan keniscayaan transformasi jaminan benda (fixed collateral) menjadi jaminan tunai (cash collateral), penulis mencoba melakukan penelitian untuk

\footnotetext{
${ }^{11}$ Sigit Ardianto dan Ahmad Fikri, "Permasalahan Hukum Seputar Gadai Ganda dan Gadai Ulang” Jurnal Ilmu Hukum Padjadjaran, Vol. XXXIV No. 2. Oktober 2009, hlm 4.

${ }^{12}$ Yusup Anwar, "Pendekatan Analisis Ekonomi Terhadap Hukum Nasional", Jurnal Ilmu Hukum Litigasi, Vol. 4 No. 1 Oktober 2003, hlm. 72

${ }^{13}$ Yeti Sumiati, "Pengaruh Privatisasi Dalam Pembangunan Ekonomi”, Jurnal Ilmu Hukum Litigasi, Vol. 4 No. 1 Oktober 2003, hlm 52.
} 
mencari dan memperoleh data tentang praktek transformasi jaminan pada salah satu cabang bank swasta nasional yang berdomisili di Bandung. Upaya penulis tidak sia-sia karena ternyata ada pemilik barang (emas murni) yang telah melakukan transformasi emas murni miliknya dalam jumlah tertentu di bank itu dengan mekanisme: penyerahan, penaksiran harga, pemasukan ke rekening bank dan ternyata nantinya dapat dijadikan jaminan kredit orang tersebut pada bank tersebut apabila suatu saat orang itu membutuhkan pinjaman kredit.

Praktek transformasi tersebut menjadi bahan yang berharga karena merupakan langkah awal yang baik. Langkah selanjutnya adalah menyusun sistem transmisi yang "mirip SWIFT" untuk langkah ini penulis belum menemukan data tentang adanya praktek di lapangan. Namun demikian, penulis berpendapat bahwa penyusunan sistem transmisi tersebut dapat dilakukan oleh Bank Indonesia dengan adanya instrumen hukum:

Pertama, kita sudah memiliki peraturan yang berbentuk Undang-undang (UU) yang memberikan perlindungan kepada nasabah yaitu UU tentang Perlindungan Konsumen. Pihak yang menjadi nasabah dalam penjaminan tunai ini adalah bank yang memberikan kredit yang dijamin dengan jaminan tunai. UU lain yang berperan sangat penting bagi penyelenggaraan sistem transmisi jaminan perbankan adalah UU tentang Informasi dan Transaksi Elektronik (UU ITE) yang mengatur tentang penyelenggaraan Sistem Informasi dan Transaksi Elektonik. UU ITE ini merupakan undang-undang yang menjadi dasar penyusunan dan pengaturan sistem transformasi jaminan.

Kedua, Bank Indonesia telah mengeluarkan berbagai peraturan dalam bentuk Peraturan Bank Indonesia (PBI) yang mengatur mengenai penggunaan teknologi informasi dalam kegiatan perbankan di Indonesia, yaitu PBI tentang Sistem Komunikasi Antar Bank, PBI tentang Penerapan Manajemen Resiko Dalam Perbankan Elektronik, dan PBI Tentang Sistem Informasi Debitur.

Ketiga, Bank Indonesia juga telah mengeluarkan berbagai Peraturan Bank Indonesia (PBI) yang berkenaan dengan kewajiban bank melaksanakan peraturan yang bersifiat memaksa demi kesehatan bank dan perlindungan kepada nasabah, antara lain: PBI No. 7/7/PBI/2005 Penyelesaian Pengaduan Nasabah; PBI No. 11/25/PBI/ 2009 tentang Perubahan atas PBI No. 5/8/PBI/2003 tentang Penerapan manajemen Resiko Bagi Bank Umum; dan PBI No. 13/2/PBI/2011 tentang Pelaksanaan Fungsi Kepatuhan Bank Umum. 
Berdasarkan informasi dari inventarisasi peraturan-peraturan tersebut di atas dapat dibuktikan bahwa penyusunan dan pengaturan sistem transmisi perbankan, termasuk transmisi jaminan, sudah ada dasar hukumnya dalam hukum positif. Dengan demikian suatu keniscayaan bagi Bank Indonesia untuk menyusun dan mengatur "SWIFT" versi Indonesia.

Perspektif yang lain adalah banyaknya aset jaminan berupa emas yang disimpan di bank-bank internasional yang dimiliki orang-orang Indonesia berupa emas yang sudah ditransformasikan dalam bentuk jaminan tunai. Kondisi ini merupakan aspek penting dan menentukan dalam mewujudkan tansformasi jaminan karena syarat pokok dari penjaminan tunai adalah adanya aset yang menjadi obyek transformasi jaminan.

Keunggulan dari penjaminan tunai yang berasal dari transformasi jaminan adalah bahwa aset atau barang yang menjadi dasar transformasi tetap disimpan di kotak penyimpanan khusus di bank (save deposit box) bank yang melakukan transformasi atau bank penerbit dan tidak dialihkan atau dipindahtangankan ke bank pemberi kredit. Apabila terjadi wanprestasi dari pengelola proyek (kontraktor) maka bank penerbit akan memindahbukukan (over-booking) dari rekening giro pemilik aset ke rekening giro bank pemberi kredit, selain itu juga terjadi perubahan nilai aset dokumen-dokumen, misalkan aset semula nilainya Rp 100 triliun tercatat pada bank penerbit. Pemilik aset menandatangani perjanjian penggunaan jaminan tunai untuk menjamin pekerjaan proyek senilai Rp. 10.000.000.000.000,00, maka bank penerbit akan memindahbukukan Rp. 10.000.000.000.000,00 ke bank pemberi kredit dan dibuat dokumen baru yaitu Rp 90 triliun atas nama pemilik aset dan Rp. 10.000.000.000.000,00 atas nama bank pemberi kredit. Kalau terjadi wanprestasi maka ada 2 (dua) opsi yang dimiliki oleh bank pemberi kredit, yaitu tetap memiliki dokumen Rp. 10.000.000.000.000,00 sebagai surat berharga, atau menyerahkan dokumen sebesar Rp. 10.000.000.000.000,00 tersebut kepada bank penerbit dan menagih sejumlah uang ganti rugi sebagai akibat wanprestasi.

Keberhasilan penjaminan tunai hasil transformasi jaminan bergantung kredibililtas atau kemampuan dari bank penerbit. Kalau bank penerbit sehat berarti bank tersebut mampu membayar ganti rugi sebagai akibat wanprestasi dari pihak yang dijaminnya, bahkan dokumen yang dikeluarkan oleh bank tersebut merupakan surat berharga yang bernilai sangat tinggi.

Ke masa depan, penjaminan tunai melalui transformasi jaminan ini berpeluang menjadi bisnis baru dari orang atau perusahaan yang memiliki aset dan bekerjasama 
dengan bank-bank ternama dan sehat untuk melakukan transformasi jaminan tersebut karena bank tersebut akan menerima yang jasa (fee based income) yang berarti memperoleh pendapatan di luar pendapatan dari bunga bank dan denda.

Apabila sistem transformasi dan transmisi jaminan ini nantinya sudah diterapkan di Indonesia maka semua proyek infrastruktur yang permohonan kreditnya sudah disetujui oleh sindikasi kredit internasional dapat dijamin dengan bank garansi oleh pemilik janinan tunai melalui jasa bank penerbit. Dengan demikian permasalahan jaminan untuk proyek-proyek infrastruktur dapat segera diatasi.

\section{Penutup}

Penelitian ini menyimpulkan sebagai berikut. Pertama, sistem hukum jaminan yang berlaku pada saat ini di Indonesia belum menjamin kepastian bagi para pengelola proyek infrastruktur dalam memperoleh kepercayaan penyaluran dana yang besar dari sindikasi kredit internasional. Kedua, Sistem Hukum Jaminan di Indonesia saat ini belum dapat mengatasi permasalahan: nilai jaminan yang besar, jenis jaminan yang nilainya kecil yang tidak sepadan dengan besarnya plafon kredit, terjadinya perubahan nilai proyek yang relatif besar dan eksekusi jaminan yang melibatkan sistem hukum negara lain.

Hambatan-hambatan yang terjadi dalam hal pengintegrasian Sistem Jaminan Perbankan di Indonesia dengan Sistem SWIFT (Society Worldwide Interbank Financial Telecommunication) dalam transmisi jaminan keuangan internasional adalah hambatan hukum dan non hukum. Hambatan hukum menyangkut pemakaian hukum asing dan forum asing sebagai lembaga penyelesaian sengketa. Hambatan non hukum menyangkut besarnya biaya SWIFT serta besarnya biaya-biaya lain sebagai akibat hambatan hukum.

Ketiga, perspektif pengaturan tentang transformasi dan transmisi jaminan kebendaan menjadi jaminan tunai dapat dilakukan dengan dua alternatif, yaitu alternatif pertama, yang merupakan rencana jangka panjang, yaitu memperbaiki sistem hukum jaminan, dan memperbaiki birokrasi dan kinerja manajemen perbankan dan para penegak hukum di Indonesia sehingga sistem SWIFT ini tidak terhambat masuk ke sistem perbankan nasional. Alternatif kedua, yang merupakan alternatif jangka pendek, yaitu Bank Indonesia menyusun sistem dan Peraturan Bank 
Indonesia tentang transformasi dan transmisi jaminan benda menjadi jaminan tunai, serta pengintegrasian kedalam sistem SWIFT.

Dalam rangka mengantisipasi semakin banyaknya kredit sindikasi internasional di Indonesia maka sebaiknya dilakukan perubahan paradigma dalam sistem hukum perjanjian dan sistem hukum jaminan di Indonesia yang memungkinkan penjaminan kredit yang besar dengan memperhatian prinsip efisiensi dan efektifitas. Diharapkan Sistem Jaminan yang berlaku di Indonesia dapat disinergikan dengan dengan Sistem Perbankan Internasional serta terwujud harmonisasi sistem hukum jaminan di Indonesia dan internasional. Dengan adanya paradigma baru tersebut sistem hukum jaminan di Indonesia menjadi berstandart internasional sehingga sistem SWIFT tidak mengalami kesulitan masuk ke Indonesia.

Dalam upaya mengatasi terbengkalainya proyek-proyek infra struktur pada saat ini sebaiknya Bank Indonesia mengatur transformasi dan transmisi jaminan benda menjadi jaminan tunai yang dapat ditransmisikan melalui "SWIFT versi Indonesia" maupun SWIFT internasional yang dipakai saat ini. Dua alternatif dapat dilakukan oleh Bank Indonesia dalam mengaturnya, yaitu alternatif pertama dan kedua sebaiknya dilakukan secara bersama-sama (simultan) dengan memperhatikan harmonisasi antar sistem hukum.

Perlu tindak lanjut dari artikel ini untuk diteliti oleh para peneliti dari: Bank Indonesia, Departemen Hukum dan Perundang-Undangan serta para praktisi hukum untuk menyusun konsep "infra struktur hukum" dan mengatur sistem transformasi jaminan benda menjadi jaminan tunai serta transmisi jaminannya.

\section{Daftar Pustaka}

Anwar, Yusup, "Pendekatan Analisis Ekonomi Terhadap Hukum Nasional", Jurnal Ilmu Hukum Litigasi, Vol. 4 No. 1 Oktober 2003.

Ardianto, Sigit dan Ahmad Fikri, "Permasalahan Hukum Seputar Gadai Ganda dan Gadai Ulang" Jurnal Ilmu Hukum Padjadjaran Vol. XXXIV No. 2. Oktober 2009.

Bahsan, M., Hukum Jaminan dan Jaminan Kredit Perbankan Indonesia, PT. Raja Grafindo Persada, Jakarta, 2007.

Harnitijo Soemitro, Ronny, Metodologi Penelitian dan Jurimetri, Ghalia Indonesia, Jakarta, 1994.

Kristianto, Fennike, Kewenangan Menggugat Pailit dalam Perjanjian Kredit Sindikasi, Minerva Athena Pressindo, Jakarta, 2009. 
Muhamad, Abdulkadir, Hukum dan Penelitian Hukum, PT Citra Aditya Bhakti, Bandung, 2004.

Murwaji, Tarsisius, "Dampak Otonomi Daerah Terhadap Investasi Pertambangan”, Jurnal Ilmu Hukum Litigasi, Vol. 5 No. 3 Oktober 2004.

Remy Sjahdeni, Sutan, Kredit Sindikasi: Proses, Teknik Pemberian dan Aspek Hukumnya, Jakarta, PT. Pustaka Grafiti, 2008.

Ridwan Widyadharma, Ignatius, Hukum Sekitar Perjanjian Kredit, Universitas Diponegoro, Semarang, 1997.

Sumiati, Yeti, "Pengaruh Privatisasi Dalam Pembangunan Ekonomi", Jurnal Ilmu Hukum Litigasi, Vol. 4 No. 1 Oktober 2003.

Suseno, Sigid, "Cybercrime, Pengaturan dan Penegakan Hukumnya di Indonesia dan Amerika Serikat", Jurnal Ilmu Hukum Padjadjaran, Vol. XXXIII No. 1. April 2009.

Usman, Racmadi, Aspek-Aspek Hukum Perbankan di Indonesia, PT. Gramedia Pustaka Utama, Jakarta, 2001. 